\title{
Greengram Livelihood Security in Pali District through Front Line Demonstrations
}

\author{
Aishwarya Dudi ${ }^{*}$ and M.L. Meena ${ }^{2}$ \\ ${ }^{1}$ SMS (Home Science), ICAR-CAZRI, Krishi Vigyan Kendra, Pali-Marwar \\ (Rajasthan) 306401, India \\ ${ }^{2}$ SMS (Agricultural Extension), ICAR-CAZRI, Krishi Vigyan Kendra, Pali-Marwar \\ (Rajasthan) 306401, India \\ *Corresponding author
}

A B S T R A C T

Pulses are important food crops for human consumption and animal feed. The total production of pulses in the world was 14.76 billion tones from the area of 14.25 billion hectares in the year 2014-15 while in India total pulses production was 18.58 million tons from the area of 23.63 million hectares in the year 2016-17 (DES 2017). The study in total

\begin{tabular}{|l|}
\hline Ke y w o r d s \\
Adoption, Frontline \\
demonstration, \\
Greengram, \\
Livelihood and gap \\
analysis
\end{tabular}
65 frontline demonstrations were conducted on farmers' fields in villages viz., Sari ki Dhani, Bedkallan, Rampura, Kushalpura and Balara of Pali district during 2012-13, 201314, 2014-15, 2015-16 and 2016-17 to demonstrate production potential and economic benefit of improved technologies comprising sowing method, nutrient management and chemical weed control and adoption of whole package of practices for the crop. After sowing application (within two days of sowing) of weedicide Pendimethalin at $1.0 \mathrm{~kg} / \mathrm{ha}$ in 500 liters of water used for effective control of the weeds during kharif season in rainfed condition. The findings of the study revealed that improved technology recorded a mean yield of $1056 \mathrm{~kg} / \mathrm{ha}$ which was $24.5 \%$ higher than obtained with farmers' practice ( 850 $\mathrm{kg} / \mathrm{ha}$ ). The extension gap, technology gap and technology index were $226 \mathrm{~kg} / \mathrm{ha}, 393.8$ $\mathrm{kg} / \mathrm{ha}$ and $27.1 \%$, respectively. An additional investments of Rs. 1720 per ha coupled with scientific monitoring of demonstrations and non-monetary factors resulted in additional return of Rs. 10459 per ha. Higher mean net income of Rs. 49342/ha with a Benefit: Cost ratio of 3.7 was obtained with improved technologies in comparison to farmers' practices (Rs. 38883/ha). The frontline demonstrations conducted on greengram at the farmers' field revealed that the adoption of improved technologies significantly increased the yield as well as yield attributing traits of crop and also the net returns to the farmers.

\section{Introduction}

Pulses are important food crops for human consumption and animal feed. Being leguminous in nature, they are considered to be important components of cropping systems because of their viability to fix atmospheric nitrogen, add substantial amounts of organic matter to the soil and produce reasonable yields with low inputs under harsh climatic and soil conditions. Moong- wheat cropping system is predominant and is continuously 
practiced by the farmers in the arid zone of Rajasthan. There is evidence of system productivity stagnation, nutrient water imbalances and increased insect-pest and diseases incidence due to prolonged use of this cereal dominated system source. Greengram (Vigna radiate L. Wilczek.) is the third important pulse crop in India. It can be grown both as kharif greengram and summer green gram. With the advent of short duration, MYMV (Mungbean yellow mosaic virus) tolerant and synchronous maturing varieties of greengram (55-60 days), there is a big opportunity for successful cultivation of greengram in green gram-wheat rotation without affecting this popular cropping pattern.

Greengram belonging to family Legueminoseae, is a tropical and sub-tropical grain legume, adapted to different types of soil conditions and environments (kharif, spring, summer). It ranks third in India after chickpea and pigeonpea. It has strong root system and capacity to fix the atmospheric nitrogen into the soil and improves soil health and contributes significantly to enhancing the yield of subsequent crops (Jat et al., 2012). However the production and productivity is very low in greengram mainly due to its cultivation in resource poor lands with minimum inputs, non-synchronous maturity and indeterminate growth habit. Greengram yield is also affected by insect-pests and diseases, especially by greengram yellow mosaic virus (MYMV) and Cercospora leaf spot (CLS). There is a strong need to develop the lines/varieties which give outstanding and consistent performance in kharif season over diverse environment. Development of varieties with high yield and stable performance is a prime target of all greengram improvement programmes. The total production of pulses in the world was 14.76 billion tones from the area of 14.25 billion hectares in the year 2014-15 while in India total pulses production was 19.78 million tons from the area of 23.63 million hectares in the year 2014-15. Whereas in Rajasthan, the total pulses production was 1.55 million tons from the area of 3.78 million hectares. The greengram production among pulses was 3.73 lacs tons from the area of 8.85 hectares in Rajasthan in the year 2013-14. The major cultivation of greengram is based upon rainfed conditions (Govt. of Rajasthan, 2016-17). Pali district stands first rank in term of area and production of greengram in the state. In this district, the greengram crop is grown in an area of 2.46 lacs ha with an annual production of over 1.30 tones (Govt. of Rajasthan, 201617).

The Front Line Demonstration is an important method of transferring the latest package of practices in totality to farmers. By which, farmers learn latest technologies of oilseeds and pulses production under real farming situation at his own field, which may lead to higher adoption. Further, these demonstrations are designed carefully where provisions are made for speedy dissemination of demonstrated technology among farming community through organization of other supportive extension activities, such as field days and farmers convention. The main objective of the Front Line Demonstration is to demonstrate newly released crop production and protection technologies and management practices at the farmers' field under different agro-climatic regions and farming situations. While demonstrating the technologies at the farmer's field, the scientists are required to study, the factors contributing to higher crop production, field constraints of production and thereby generating production factor and feedback information. Front Line Demonstrations are conducted in a block of two to four hectares of land in order to have better impact of the demonstrated technology on the farmers and field level extension functionaries with full package of practices. Keeping in view the 
present study was done to analyze the performance and to promote the FLD on greengram production.

\section{Materials and Methods}

In total 65 frontline demonstrations were conducted on farmers' field in villages Sari ki Dhani, Bedkallan, Rampura, Kushalpura and Balara of Pali district during 2012-13, 201314, 2014-15, 2015-16 and 2016-17. Each demonstration was conducted on an area of 0.4 ha, and 1.0 ha area adjacent to the demonstration plot was kept as farmers' practices. The package of improved technologies like line sowing, nutrient management, seed treatment and whole package were used in the demonstrations. The variety of greengram SML 668 was included in demonstrations methods used for the present study with respect to FLDs and farmers' practices are given in Table 1.

In case of local check plots, existing practices being used by farmers were followed. In general, soils of the area under study were sandy loam and medium to low in fertility status. The spacing was $30 \mathrm{~cm}$ between rows and $10 \mathrm{~cm}$ between plants in the rows. The thinning and weeding was done invariably 30 35 days after sowing to ensure recommended plant spacing within a row because excess population adversely affects growth and yield of crop. Seed sowing was done in the first week of July with a seed rate of $15-20 \mathrm{~kg} / \mathrm{ha}$. Other management practices were applied as per the package of practices for kharif crops by Department of Agriculture, Agro-climatic Zone IIb Jalore (DOA, 2017). Data with respect to grain yield from FLD plots and from fields cultivated following local practices adopted by the farmers of the area were collected and evaluated. Potential yield was taken in to consideration on the basis of standard plant population (404440 plants/ha) and average yield per plant $22.5 \mathrm{gm} /$ plant under recommended package of practices with 30 X $10 \mathrm{~cm}$ crop geometry (Chandra 2010). Different parameters as suggested by Yadav et al., (2004) was used for gap analysis, and calculating the economic. The details of different parameters and formula adopted for analysis are as under:

Extension gap $=$ Demonstration yield Farmers' practice yield

Technology gap $=$ Potential yield Demonstration yield

Technology index $=$

Potential Yield-Demonstration Yield Potential Yield ${ }^{100}$

Additional cost $=$ demonstration Cost Farmers' practice cost

Effective gain $=$ Additional Returns Additional cost

Additional returns $=$ Demonstration returns Farmers' practice returns

Incremental B: C ratio $=\frac{\text { Additional Returns }}{\text { Additional Cost }}$

\section{Results and Discussion}

\section{Yield attributing traits}

The number of productive pods per plant under improved technology were 78.8, 89.4, $70.4,82.6$ and 74.2 as against local check (farmers' practices), 45.7, 53.5, 51.9, 33.3 and 48.9 during the year 2012-13, 2013-14, 201415, 2015-16 and 2016-17, respectively (Table 2). There was an increase of $69.4,67.1,35.6$, 48.3 and $51.7 \%$ in number of productive pods under demonstration of improved technology over farmers' practice. 
Table.1 Particulars showing the details of greengram grown under FLD and farmers' practice

\begin{tabular}{|c|c|c|}
\hline Operation & Existing practice & Improved practices demonstrated \\
\hline Line sowing & Broad casting of seed & $\begin{array}{l}\text { Spacing } 40 \mathrm{~cm} \text { between rows and } 10 \mathrm{~cm} \\
\text { between plants in the rows }\end{array}$ \\
\hline Seed treatment & No seed treatment & Seed treatment with Bavistin $2 \mathrm{gm} / \mathrm{kg}$ seed \\
\hline $\begin{array}{l}\text { Weed } \\
\text { management }\end{array}$ & No weed management & $\begin{array}{l}\text { Weeds control by using herbicide } \\
\text { Pendimethaline } 1 \mathrm{~kg} / \mathrm{ha} \text { in } 500 \text { liter of water as } \\
\text { pre-emergence treatment for effective control } \\
\text { of weeds within two days after sowing. }\end{array}$ \\
\hline $\begin{array}{l}\text { Nutrient } \\
\text { management }\end{array}$ & $\begin{array}{l}\text { Only FYM and no } \\
\text { fertilizer application }\end{array}$ & $\begin{array}{l}10 \text { tons/ha farm yard manure and } 20 \mathrm{~kg} / \mathrm{ha} \\
\text { nitrogen }\end{array}$ \\
\hline Whole packag & $\begin{array}{l}\text { Farmers are } \\
\text { cultivating the } \\
\text { greengram crop } \\
\text { without adoption of } \\
\text { any improved } \\
\text { technology }\end{array}$ & $\begin{array}{l}\text { All the crop (production and protection) } \\
\text { management practices as per the package of } \\
\text { practices for kharif crop by SKRAU, Bikaner, } \\
\text { were followed for raising the crop }\end{array}$ \\
\hline
\end{tabular}

Table.2 Yield attributing traits of greengram

\begin{tabular}{|c|c|c|c|c|c|c|c|c|c|}
\hline \multirow[t]{2}{*}{ Year } & \multicolumn{3}{|c|}{ Number of pods/plant } & \multicolumn{3}{|c|}{ Number of seeds/pods } & \multicolumn{3}{|c|}{$\begin{array}{l}\text { Seed weight (in } 100 \text { pods } \\
\text { gm) }\end{array}$} \\
\hline & IT & FP & $\begin{array}{l}\% \\
\text { increased }\end{array}$ & IT & FP & $\begin{array}{l}\% \\
\text { increased }\end{array}$ & IT & FP & $\begin{array}{l}\% \\
\text { increased }\end{array}$ \\
\hline 2012-13 & 78.8 & 45.7 & 69.4 & 10.5 & 6.7 & 56.7 & 55.7 & 39.8 & 39.9 \\
\hline 2013-14 & 89.4 & 53.5 & 67.1 & 10.2 & 5.8 & 75.9 & 57.6 & 37.8 & 52.4 \\
\hline 2014-15 & 70.3 & 51.9 & 35.6 & 8.9 & 6.3 & 41.3 & 55.3 & 40.6 & 36.2 \\
\hline 2015-16 & 82.6 & 33.3 & 48.3 & 9.0 & 5.9 & 52.5 & 60.0 & 42.7 & 40.5 \\
\hline $2016-17$ & 74.2 & 48.9 & 51.7 & 9.5 & 6.5 & 46.1 & 55.0 & 35.4 & 55.4 \\
\hline Average & 79.1 & 46.7 & 54.4 & 9.6 & 6.2 & 54.5 & 56.7 & 39.3 & 44.9 \\
\hline
\end{tabular}

IT= Improved Technology; FP = Farmers Practice

Table.3 Seed yield of greengram as affected by improved and farmer practices in farmers' fields

\begin{tabular}{|c|c|c|c|c|c|c|}
\hline \multirow[t]{2}{*}{ Year } & \multirow{2}{*}{$\begin{array}{l}\text { Area } \\
\text { (ha) }\end{array}$} & \multirow{2}{*}{$\begin{array}{l}\text { Demonst } \\
\text { ration } \\
\text { (No.) }\end{array}$} & \multicolumn{2}{|c|}{ Yield kg/ha } & \multirow{2}{*}{\begin{tabular}{|l} 
Additional \\
yield (kg/ha) \\
over farmer \\
practice
\end{tabular}} & \multirow{2}{*}{$\begin{array}{l}\% \text { increased } \\
\text { in yield over } \\
\text { farmers } \\
\text { practice }\end{array}$} \\
\hline & & & IT & $\mathbf{F P}$ & & \\
\hline 2012-13 & 05.5 & 10 & 1080 & 790 & 290 & 36.7 \\
\hline 2013-14 & 08.0 & 15 & 1130 & 890 & 240 & 26.9 \\
\hline $2014-15$ & 10.5 & 10 & 1003 & 860 & 143 & 16.7 \\
\hline 2015-16 & 10.5 & 15 & 1045 & 830 & 215 & 25.9 \\
\hline $2016-17$ & 10.5 & 15 & 1023 & 880 & 143 & 16.3 \\
\hline Average & 9.0 & 13.0 & 1056.2 & 850 & 206.2 & 24.5 \\
\hline
\end{tabular}


Table.4 Technological gap analysis of frontline demonstrations on greengram farmers' field

\begin{tabular}{|l|l|l|l|l|l|l|l|l|}
\hline Years & $\begin{array}{l}\text { Number } \\
\text { of FLDs }\end{array}$ & $\begin{array}{l}\text { Potentia } \\
\text { l yield } \\
\left(\mathrm{kgha}^{-1}\right)\end{array}$ & $\begin{array}{l}\text { FLD } \\
\text { yield } \\
\left(\mathrm{kgha}^{-1}\right)\end{array}$ & $\begin{array}{l}\text { FP } \\
\text { yield } \\
\left(\mathrm{kgha}^{-1}\right)\end{array}$ & $\begin{array}{l}\text { \% } \\
\text { increa } \\
\text { sed }\end{array}$ & $\begin{array}{l}\text { EG } \\
(\mathrm{kgha-1})\end{array}$ & $\begin{array}{l}\text { TG } \\
\left(\mathrm{kgha}^{-1}\right)\end{array}$ & $\begin{array}{l}\text { TI } \\
\left(\mathrm{kgha}^{-1}\right)\end{array}$ \\
\hline $\mathbf{2 0 1 2 - 1 3}$ & 10 & 1450 & 1080 & 790 & 36.7 & 290 & 370 & 25.5 \\
\hline $\mathbf{2 0 1 3 - 1 4}$ & 15 & 1450 & 1130 & 890 & 26.9 & 240 & 320 & 22.1 \\
\hline $\mathbf{2 0 1 4 - 1 5}$ & 10 & 1450 & 1003 & 860 & 16.6 & 143 & 447 & 30.8 \\
\hline $\mathbf{2 0 1 5}-\mathbf{1 6}$ & 15 & 1450 & 1045 & 801 & 30.5 & 244 & 405 & 27.9 \\
\hline $\mathbf{2 0 1 6 - 1 7}$ & 15 & 1450 & 1023 & 810 & 26.3 & 213 & 427 & 29.4 \\
\hline A verage & $\mathbf{1 3 . 0}$ & $\mathbf{1 4 5 0}$ & $\mathbf{1 0 5 6 . 2}$ & $\mathbf{8 3 0 . 2}$ & $\mathbf{2 7 . 4}$ & $\mathbf{2 2 6}$ & $\mathbf{3 9 3 . 8}$ & $\mathbf{2 7 . 1}$ \\
\hline
\end{tabular}

$\mathrm{EG}=$ Extension gap; $\mathrm{TG}=$ Technology gap; $\mathrm{TI}=$ Technology index; $\mathrm{FP}=$ Farmers practices

Table.5 Cost of cultivation (Rs./ha), net return (Rs./ha) and benefit: cost-ratio of greengram as affected by improved and farmers' practice

\begin{tabular}{|c|c|c|c|c|c|c|c|c|c|}
\hline \multirow[t]{2}{*}{ Years } & \multicolumn{2}{|c|}{$\begin{array}{l}\text { Cost of } \\
\text { cash input } \\
\text { (Rs./ha) }\end{array}$} & \multirow{2}{*}{$\begin{array}{c}\text { Additio } \\
\text { nal cost } \\
\text { in } \\
\text { demo. } \\
\text { (Rs./ha) }\end{array}$} & \multirow{2}{*}{$\begin{array}{c}\text { Sale } \\
\text { price } \\
\text { (MSP) of } \\
\text { grain } \\
\text { (Rs./qtl.) }\end{array}$} & \multicolumn{2}{|c|}{$\begin{array}{l}\text { Total returns } \\
\text { (Rs./ha) }\end{array}$} & \multirow{2}{*}{$\begin{array}{l}\text { Additional } \\
\text { returns in } \\
\text { demo. } \\
\text { (Rs./ha) }\end{array}$} & \multirow[t]{2}{*}{$\begin{array}{l}\text { Effective } \\
\text { gain } \\
\text { (Rs./ha) }\end{array}$} & \multirow{2}{*}{$\begin{array}{l}\text { INC } \\
\text { B:C } \\
\text { ratio } \\
\text { (IBCR) }\end{array}$} \\
\hline & IP & FP & & & IP & FP & & & \\
\hline 2012-13 & 6000 & 4500 & 1500 & 4500 & 48600 & 35550 & 13050 & 11550 & 4.5 \\
\hline 2013-14 & 6500 & 4800 & 1700 & 4650 & 52545 & 41385 & 11160 & 9460 & 3.1 \\
\hline $2014-15$ & 7500 & 5200 & 2300 & 4600 & 46138 & 39560 & 6578 & 4278 & 3.8 \\
\hline $2015-16$ & 6300 & 5000 & 1300 & 4620 & 48279 & 37422 & 10857 & 9557 & 3.9 \\
\hline $2016-17$ & 7000 & 5200 & 1800 & 5000 & 51150 & 40500 & 10650 & 8850 & 3.1 \\
\hline Average & 6660 & 4940 & 1720 & 4674 & 49342 & 38883 & 10459 & 8739 & 3.7 \\
\hline
\end{tabular}

IT= Improved Technology; FP= Farmers Practices

The average number of productive pods per plant in improved technology was 79.1 and 46.7 under farmers' practice, thus there were $54.4 \%$ more pods per plant under improved technology demonstrations. The findings confirm with the findings of Yadav et al., (2007) and Meena et al., (2011) and Rajni et al., (2013).

\section{Seed yield $(\mathrm{kg} / \mathrm{ha})$}

The productivity of greengram under improved production technology ranged between $1003-1130 \mathrm{~kg} / \mathrm{ha}$ with mean yields of $1056.2 \mathrm{~kg} / \mathrm{ha}$ (Table 3 ). The productivity under improved technology was 1080,1130 , 1003,1045 and $1023 \mathrm{~kg} \mathrm{ha}^{-1}$ during 2012-13, 2013-14, 2014-15, 2015-16 and 2016-17, respectively as against a yield range between 790 to $890 \mathrm{~kg} \mathrm{ha}^{-1}$ under farmers' practice.

In comparison to farmer's practice, there was an increase of 36.7, 26.9, 16.7, 25.9 and $16.3 \%$ in productivity of greengram under improved technologies in 2012-13, 2013-14, 2014-15, 2015-16 and 2016-17, respectively.

The increased grain yield with improved technologies was mainly because of line sowing use of nutrient management and weed 
management. The findings are confirm with the findings of Singh and Meena (2011), Poonia and Pithia (2011) and Meena et al., (2012).

\section{Gap analysis}

Evaluation of findings of the study (Table 4) stated that an extension gap of 143 to $290 \mathrm{~kg}$ $\mathrm{ha}^{-1}$ was found between demonstrated technology and farmers' practice and on average basis the extension gap was $226 \mathrm{~kg}$ $\mathrm{ha}^{-1}$. The extension gap was highest $(290 \mathrm{~kg}$ $\mathrm{ha}^{-1}$ ) during 2012-13 and lowest (143 $\mathrm{kg} \mathrm{ha}^{-1}$ ) during 2013-14. Such gap might be attributed to adoption of improved technology especially high yielding varieties sown with the help of seed cum fertilizers drill with balanced nutrition, weed management and appropriate plant protection measures in demonstrations which resulted in higher grain yield than the traditional farmers' practices. The study further exhibited a wide technology gap during different years. It was lowest (320 $\mathrm{kg} \mathrm{ha}^{-1}$ ) during 2012-13 and highest (447 kg $\mathrm{ha}^{-1}$ ) during 2013-14. The average technology gap of all the years was $393.8 \mathrm{~kg} \mathrm{ha}^{-1}$. The difference in technology gap in different years is due to better performance of recommended varieties with different interventions and more feasibility of recommended technologies during the course of study. Similarly, the technology index for all demonstrations in the study was in accordance with technology gap. Higher technology index reflected the inadequate transfer of proven technology to growers and insufficient extension services for transfer of technology. On the basis of three years study, overall $27.1 \%$ technical index was recorded, which was reduced from $25.5,22.1,30.8,27.9$ and 29.4 during 201213, 2013-14, 2014-15, 2015-16 and 2016-17 respectively.. Hence, it can be inferred that the awareness and adoption of improved varieties with recommended scientific package of practices have increased during the advancement of study period. These findings are in the conformity of the results of study carried out by Chandra (2010), Meena and Singh (2013) and Dayanand et al., (2012).

\section{Economics}

Different variables like seed, fertilizers, biofertilizers and pesticides were considered as cash input for the demonstrations as well as farmers practice and on an average additional investment of Rs. 1720 per ha was made under demonstrations. Economic returns as a function of gain yield and MPS sale price varied during different years. The maximum returns (Rs. 13050) during the year 2012-13 were obtained due to high grain yield and higher MPS sale rates as declared by GOI.

The higher additional returns and effective gain obtained under demonstrations could be due to improved technology, non-monetary factors, timely operations of crop cultivation and scientific monitoring. The lowest and highest incremental benefit cost ratio (IBCR) were 3.1 and 4.5 in 2015-16 and 2012-13, respectively (Table 5) depends on produced grain yield and MPS sale rates.

Overall average IBCR was found 3.7. The results confirm with the findings of front line demonstrations on pulses by Yadav et al., (2004), Gauttam et al., (2011), Lothwal (2010), Chaudhary (2011), Dayanand et al., (2012), Meena and Dudi (2012) and Meena and Singh (2016), Dash and Rautaray (2017) and Dash et al., (2018).

It may be concluded that the frontline demonstrations conducted on greengram at the farmers' field revealed that the adoption of improved technologies significantly increased the yield as well as yield attributing traits of the crop and also the net returns to the farmers. So, there is a need to disseminate 
the improved technologies among the farmers with effective extension methods like training and demonstrations. The farmers' should be encouraged to adopt the recommended package of practices realizing for higher returns.

\section{References}

Chandra, G. 2010. Evaluation of frontline demonstrations of greengram in Sunderban, West Bengal. Journal of Indian Society of Costal Agricultural Research 28:12-15.

Chaudhary, S. 2012. Impact of front lie demonstration on adoption of improved greengram production technology in Nagaur district of Rajasthan. M.Sc. Thesis, SKRAU, Bikaner.

Dash, S.R. and Rautaray, B.K. 2017. Growth parameter and yield of green gram varieties (Vigna radiate L.) in East and South East Coastal Plain of Odisha, India. Int. J. Curr. Microbiol. App. Sci. 6(1):1517-1523.

Dash, S.R., B.K. Rautaray and Dhal, A. 2018. Perception and Constraints faced by Pulse Growers and yield gap analysis of Green Gram (Vigna radiata L.) in East and South East Coastal Plain of Odisha, India. Int. J. Curr. Microbiol. App. Sci. 7(01): 338-346.

Dayanand, Verma, R.K. and Mahta, S.M. 2012. Boosting the mustard production through front line demonstrations. Indian Research Journal of Extension Education 12(3):121-123.

DOA, 2017. Production and productivity of kharif pulses in Agro-climatic zone of Rajasthan. Pp 122-128.

Gauttam, U.S., Paliwal, D.K. and Singh, S.R.K. 2011. Impact of frontline demonstrations on productivity enhancement of chickpea. Indian Journal of Extension Education, 48 (3\&4): 10-13.
GOR, 2017. Vital Agricultural Statistics, Govt. of Rajasthan, Pant Krashi Bhawan, Jaipur. Pp 23-27.

Jat, M.L., Dayanand, and Singh, D. 2012. Production and productivity of pulses in India. Agricultural Extension Review 21 (2):12-16.

Lothwal, O.P. 2010. Evaluation of front line demonstrations on black gram in irrigated agro-ecosystem. Annals of Agricultural Research, 31 (1\&3):24-27.

Meena, M.L. and Dudi, A. 2012. On farm testing of chickpea cultivars for site specific assessment under rainfed condition of western Rajasthan. Indian Journal of Extension Education, 48 (3\&4): 93-97.

Meena, M.L. and Singh, D. 2016. Productivity enhancement and gap analysis of moth bean (Vigna acontifilia (Jacq.)) through improved production technologies of farmers' participatory mode. Indian Journal of Dryland Agricultural Research and Development, 31 (1):68-71.

Meena, O.P., Sharma K.C., Meena, R.H. and Mitharwal, B.S. 2012. Technology transfer through FLDs on mung bean in semi-arid rgion of Rajasthan. Rajasthan Journal of extension Education 20:182186.

Poonia, T.C. and Pithia, M.S. 2011. Impact of front line demonstrations on chickpea in Gujarat. Legume Research 34(4):304307.

Raj, A.D., Yadav, V. and Rathod, J.H. 2013. Impact of front line demonstrations (FLD) on the yield of pulses. International Journal of Scientific and Research 3(9):1-4.

Rajni, Singh, N.P. and Singh, P. 2014. Evaluation of frontline Demonstrations on yield and economic analysis of summer moong in Amritsar district of Punjab. Indian Journal of Extension Education. 50 (1\&2):87-89. 
Singh, B.S. and Chauhan, T.R. 2010. Adoption of mungbean production technology in arid zone of Rajasthan. Indian Research Journal of Extension 10(2):73-77.

Singh, D. and Meena, M.L. 2011. Boosting seed spices production technology through front line demonstrations. International Journal of Seed Spices 1(1):81-85.

Yadav, D.B, Kambhoj, B.K. and Garg, R.B. 2004. Increasing the productivity and profitability of sunflowers through frontline demonstrations in irrigated agro-ecosystem of eastern Haryana. Haryana Journal of Agronomy 20(1):33-35.

Yadav, V.P.S., Kumar, R., Deshwal, A.K., Raman, R.S., Sharma, B.K. and Bhela, S.L. 2007. Boosting pulse production through frontline demonstration. Indian Journal of Extension Education 7 (2):12-14.

\section{How to cite this article:}

Aishwarya Dudi and Meena, M.L. 2018. Greengram Livelihood Security in Pali District through Front Line Demonstrations. Int.J.Curr.Microbiol.App.Sci. 7(04): 2637-2644.

doi: https://doi.org/10.20546/ijcmas.2018.704.300 